\title{
Review
}

\section{Insecticidal, repellent, antimicrobial activity and phytotoxicity of essential oils: With special reference to limonene and its suitability for control of insect pests}

\author{
Mohamed A. Ibrahim \\ Department of Ecology and Environmental Science, University of Kuopio, PO Box 1627, \\ FIN-70211 Kuopio, Finland, e-mail: ibrahim@uku.fi
}

Pirjo Kainulainen

MTT Agrifood Research Finland, Plant Production Research, Plant Protection, FIN-31600 Jokioinen, Finland.

Current address: Department of Ecology and Environmental Science, University of Kuopio, PO Box 1627,

FIN-70211 Kuopio, Finland

Abbas Aflatuni

MTT Agrifood Research Finland, Regional Research, Tutkimusasemantie 15, FIN-92400 Ruukki, Finland

Kari Tiilikkala

MTT Agrifood Research Finland, Plant Production Research, Plant Protection, FIN-31600 Jokioinen, Finland

Jarmo K. Holopainen

MTT Agrifood Research Finland, Plant Production Research, Plant Protection, FIN-31600 Jokioinen, Finland.

Current address: Department of Ecology and Environmental Science, University of Kuopio, PO Box 1627,

FIN-70211 Kuopio, Finland

The interest in the use of monoterpenes for insect pest and pathogen control originates from the need for pesticide products with less negative environmental and health impacts than highly effective synthetic pesticides. The expanding literature on the possibility of the use of these monoterpenes is reviewed and focused on the effects of limonene on various bioorganisms. Limonene is used as insecticide to control ectoparasites of pet animals, but it has activity against many insects, mites, and microorganisms. Possible attractive effects of limonene to natural enemies of pests may offer novel applications to use natural compounds for manipulation of beneficial animals in organic agriculture. However, in few cases limonene-treated plants have become attractive to plant damaging insects and phytotoxic effects on cultivated plants have been observed. As a plant-based natural product limonene and other monoterpenes might have use in pest and weed control in organic agriculture after phytotoxicity on crop plants and, effects on non-target soil animals and natural enemies of pest have been investigated.

Key words: monoterpenes, limonene, essential oil, natural pesticides, plant protection, deterrent, insect control 
Ibrahim, M.A. et al. Limonene in pest control

\section{Introduction}

\section{Historical perspective}

Essential oil-bearing plants have been collected from the forest and cultivated areas since preChristian time for their flavour and fragrance properties. Their volatility, which made them easy to discover in fragrant plant material and at the same time readily obtainable by simple distillation of plant parts, lent to them the term essential oil. The monoterpenes with to a lesser extent the sesquiterpenes, comprise the major components of essential oils. Monoterpenes operate as a chemical defence against herbivores and diseases, fragrances attractive to pollinators and allelopathic inhibition of seed germination and plant growth (Gershenzon and Croteau 1991, Langenheim 1994). Well-documented records show that before 1850, 20 plant species belonging to 16 different families were used for control of agricultural and horticultural pests in Western Europe and China (Needham 1986, Smith and Secoy 1981). The rich knowledge of plants with pesticide properties was not lost in China as evidenced by a recent report stating that in China different parts or extracts of 276 plant species are used as pesticides (Yang and Tang 1988).

Insecticidal properties have been recognized in the oil of many citrus fruits and in recent years, several products containing (+)-limonene, linalool, or a crude citrus oil extract have worked their way into the market place. Two of these oils, (+)-limonene and linalool are long-standing and widely used for food additives (Hooser 1990).

\section{Chemical properties of monoterpenes}

Terpenes are hydrocarbons classified by the number of five-carbon (isoprene) units that they contain. Monoterpenes contain a basic skeleton of 10-carbon atoms derived from of fusion of two $\mathrm{C}_{5}$ isoprene units. The other classes of ter- penoids are sesquiterpenes $\left(\mathrm{C}_{15}\right)$, diterpenes $\left(\mathrm{C}_{20}\right)$, triterpenes $\left(\mathrm{C}_{30}\right)$, tetraterpenes $\left(\mathrm{C}_{40}\right)$ and polyterpenes $\left(\mathrm{C}_{\mathrm{n}}\right)$. The plastids of plants are regarded to be the site of monoterpene synthesis. All terpenoid compounds are biosynthesised from isopentenyl diphosphate (IPP), which may be derived by acetate/mevalonate or pyruvate/ glyceraldehydes-3-phosphate pathway. The head-to-tail condensation of one molecule of IPP with one molecule of dimethylallyl diphosphate (DMAPP), itself derived from the reversible isomerization of IPP by IPP isomerase yields the $\mathrm{C}_{10}$ compound geranyl diphosphate (GPP) which is the immediate precursor of the monoterpenes (Lichtenthaler et al. 1997, Little and Croteau 1999).

Hydrocarbon variations that differ only in the arrangement of atoms are called isomers. Description of isomers and their chemical and biological functions are summarized in Table 1 according to Fessenden et al. (1998). Enantiomers are chiral molecules that have the same molecular formula but are mirror images of each other. Absolute configuration of chiral carbon ( $R$ or $\mathrm{S}$ ) is not dependent on the direction of optical rotation (+ or -$)$, but in each specific compound are always related, e.g. limonene has two enantiomers (R)-(+)-limonene and (S)-(-)-limonene, but the enantiomers of carvone are $(\mathrm{R})-(-)$-carvone and $(S)-(+)$-carvone. In this review we use (+ and -$)$-nomenclature, since optical isomers are related closely to the biological activity of monoterpenes. Even human sense of smell is able to discriminate the odours of the enantiomers of $\alpha$-pinene, carvone and limonene. R-limonene is the smell of lemon or orange, while smell of Slimonene is close to that of pine turpentine (Laska and Teubner 1999).

\section{Natural occurrence and functions of monoterpenes}

More than 1000 naturally occurring monoterpenes have been isolated from higher plants (Gershenzon and Croteau 1991). Monoterpenes are volatile and responsible for the characteristic 
Vol. 10 (2001): 243-259.

Table 1. Description of isomers summarized from Fessenden et al. (1998) and chemical designation of some monoterpenes.

\begin{tabular}{ll}
\hline Type of the isomers & Nomenclature \\
\cline { 2 - 2 } & Old Nescription \\
\hline
\end{tabular}

\begin{tabular}{|c|c|c|c|}
\hline \multicolumn{3}{|l|}{ A. Structural isomers } & $\begin{array}{l}\text { Different compounds that have the same molecular } \\
\text { formula, but differ in order of attachment of atoms }\end{array}$ \\
\hline \multirow[t]{3}{*}{$\begin{array}{l}\text { B. Stereoisomers } \\
\text { 1. Enantiomers } \\
\text { (optical isomers) }\end{array}$} & & & $\begin{array}{l}\text { Chiral molecules are mirror images of each other. } \\
\text { Chemical properties are similar, but physiological } \\
\text { properties differ. }\end{array}$ \\
\hline & $\begin{array}{l}\mathrm{D} \\
\mathrm{L}\end{array}$ & $\begin{array}{l}\mathrm{R} \\
\mathrm{S}\end{array}$ & $\begin{array}{l}\text { The prefixes } \mathrm{R} \text { (clockwise) and } \mathrm{S} \text { (counter clockwise) } \\
\text { indicate absolute configuration of group around chiral } \\
\text { carbon. }\end{array}$ \\
\hline & $\begin{array}{l}\mathrm{D} \\
\mathrm{L}\end{array}$ & $\begin{array}{l}+ \\
-\end{array}$ & $\begin{array}{l}\text { The prefixes }(+)-\text { and }(-) \text { - are used to designate the } \\
\text { sign of optical rotation of plane-polarized light by the } \\
\text { enantiomers }\end{array}$ \\
\hline $\begin{array}{l}\text { 2. Diastereomers } \\
\text { including achiral } \\
\text { geometric isomers }\end{array}$ & $\begin{array}{l}\text { Cis } \\
\text { Trans }\end{array}$ & $\begin{array}{l}Z \\
E\end{array}$ & $\begin{array}{l}\text { Molecules are not mirror images of each other. } \\
\text { Geometric isomers result from groups being } \mathrm{Z} \text { (same) } \\
\text { and } \mathrm{E} \text { (opposite) side. }\end{array}$ \\
\hline
\end{tabular}

odours of many plants. Most monoterpenes occur free in plant tissue, but some of them are found as glycosides. The monoterpenes occur in a variety of acyclic, monocyclic, bicyclic, and tricyclic structural types and derivates, representing one of the largest and most diverse families of natural compounds (Croteau 1987). They exist as hydrocarbons or as oxygenated moieties with aldehyde, alcohol, ketone, ester, and ether functionalities. Overall monoterpenes are insoluble in water, however, monoterpenes containing oxygen have greater solubility than hydrocarbons with comparable skeletons (Weidenhamer et al. 1993).

Because of lipophilic properties most of monoterpenes are stored in special structures as resin ducts, secretory cavities and epidermal glands (Dell and McComb 1981). Monoterpenes are most widely recognized constituents of conifers, mints (Lamiaceae), composites (Asteraceae), and citrus (Rutaceae). $\alpha$-pinene and $\beta$ pinene are among the most widely distributed monoterpenes in the plant kingdom and are the major constituents of the various volatile oils
(Schütte 1984). Overall, the variability in essential oil composition is determined both by genetic and epigenetic factors.

Generally, plants can produce a diverse range of secondary metabolites such as terpenoids, phenolic compounds and alkaloids (Benner 1993). Terpenoids are among the vast reservoir of secondry compounds produced by higher plants evolved in defence against herbivores and pathogens (Duke et al. 1991). Monoterpenes may interfere with basic behavioural functions of insects (Brattesten 1983). Some exhibit acute toxicity whereas others are repellents (Watanabe et al. 1993), antifeedants (Hough-Goldstein 1990), or disrupt on growth and development (Karr and Coats 1992) or reproduction (Sharma and Saxena 1974) and, interfere with physiological and biochemical processes (Gershenzon and Croteau 1991).

Since monoterpene composition of plant species is very distinctive, specialist herbivore insects that have only one plant species or one plant genus as host plant, use highly volatile monoterpenes as a cue to locate their specific host plant. 
Ibrahim, M.A. et al. Limonene in pest control

For many oligophagous and polyphagous insect herbivores monoterpenes have been demonstrated to act as toxins, feeding and oviposition deterrents. Thus, monoterpenes appear to play an important role in protecting plants from insect attack (Gershenzon and Croteau 1991, Langenheim 1994, Phillips and Croteau 1999). The bestknown insect neurotoxins among monoterpenes are the pyrethroids, a group of monoterpene esters found in the leaves and flowers of certain Chrysanthemum species (Harborne 1993).

Some compounds in essential oils have shown promise as natural insect pest control agents because they naturally provide plants with chemical defences against phytophagous insects and plant pathogens. These advances are reviewed in this paper with a focus on the monoterpenes and especially limonene, a compound with low toxicity to humans and having even some antitumor activity (Crowell 1999).

\section{Effects of monoterpenes on bio-organisms}

\section{Bacteria}

Essential oil of plants has been shown to have activity against human, animal and plant pathogens, as well as food poisoning bacteria. The essential oils have effects on bacteria cells or their activity. The essential oils from Melaleuca alternifolia (tea tree oil) inhibit the respiration and increase the permeability of bacterial cytoplasmic membranes of Gram-negative bacterium Escherichia coli AG 100, the Gram-positive bacterium Staphylococcus aureus NCTC 8325. These essential oils also cause potassium leakage (Cox et al. 2000). The essential oil of Cymbopogon densiflorus showed a wide spectrum of activity against Gram positive and Gram negative bacteria in the range of 250-500 and 500$1000 \mathrm{ppm}$, respectively. The main essential oil components were limonene, cymenene, p- cymene, Z- and E-carveol, carvone, iso-piperitenone, p-mentha-1 (7), 8-dien-ol, and p-mentha-2, 8-dien-1-ol. (Takaisi-Kikuni et al. 2000).

The main constituents of the oil of Calamintha nepeta (limonene, menthone, pulegone, menthol) were tested against some bacteria species, and only pulegone showed antimicrobial activity, particularly against all Salmonella species (Flamini et al. 1999). The determination of the minimal bactericidal concentration of the essential oil from the leaves of Peumus boldus (main constituents: monoterpenes $90.5 \%$, including $17 \%$ limonene) against several microorganisms showed antibacterial activities towards Gram-positive and Gram-negative bacteria. Streptococcus pyogenes and Micrococcus sp. were the more sensitive in the case of Gram-positive bacteria and Shigella sonnei in Gram-negative bacteria (Vila et al. 1999).

The antibacterial activity of the various oils (main constituents were (E)-anethole, limonene, fenchone, and methyl chavicol) hydrodistilled from the seeds of 3 varieties of Foeniculum vulgare (dulce or sweet, vulgare or bitter, and azoricum or Florence) against 25 microorganisms was evaluated. The essential oil from sweet fennel (at the early waxy seed stage) was the most effective antibacterial agent. Essential oils of Rosmarinus officinalis (from Giza, Egypt) showed a high antimicrobial activity against Cryptococcus neoformans and Mycobacterium intracellularae (Soliman et al. 1994).

In antibacterial assays, the essential oil of Origanum onites, Thymus capitatus and oregano were active against Bacillus subtilis, E. coli, Hafnia alvei, Micrococcus luteus, Proteus vulgaris, S. aureus and Streptococcus faecalis but not against $P$ seudomonas aeruginosa. O. onites, T. capitatus and oregano inhibited the growth of the 5 test fungi. It is suggested that the observed antimicrobial activities may be associated with the phenolic constituents in the essential oil of O. onites, T. capitatus and oregano (Biondi et al. 1993). Helander et al. (1998) tested the inhibitory activity of some essential oils, including (+)-carvone against E. coli $0157: \mathrm{H} 7$ and Salmonella typhymurium, and determined that, (+)- 
Vol. 10 (2001): 243-259.

carvone was among less inhibitory compounds. Chanegriha et al. (1994) reported that, limonene and terpenyl acetate both inhibited the activity of B. subtilis and E. coli.

The essential oil of Tagetes minuta inhibited the multiplication of Gram-positive and Gramnegative bacteria showing 95-100\% of inhibition (Hethelyi et al. 1987). Similarly, Hyptis suaveolens' essential oil including limonene inhibits the growth of both Gram-positive and Gramnegative bacteria (Iwu et al. 1990).

The bark essential oil of Xylopia longifolia exhibited antimicrobial properties against some microorganisms including $S$. aureus and $E$. coli (MIC values of 0.5 and $2 \mathrm{mg} / 1$ respectively) (Fuornier et al. 1993). The antimicrobial activity of the Cotinus coggygria oil was manifested by its strong inhibition of the multiplication of both Gram-positive and Gram-negative bacteria (Hethelyi et al. 1986). The main components of the essential oil of leaves and stems of Ducrosia anethifolia ( $\alpha$-pinene, myrcene, limonene, terpinolene and $\mathrm{E}-\beta$-ocimene) were active against Gram-positive bacteria, yeast and fungi (Janssen et al. 1984).

\section{Fungi}

Cox et al. (2000) reported that fungal toxicity of $M$. alternifolia essential oils to the yeast Candida albicans is based on increased permeability of the plasma membranes. Essential oil of $H$. suaveolens including limonene has mild antifungal activity against $C$. albicans (Iwu et al. 1990). Monoterpenes (1R, 2S, 5R)-Isopulegol, (R)-carvone and Isolimonene showed good fungistatic activities against $C$. albicans (Naigre et al. 1996). All essential oils hydrodistilled from the seeds of 3 varieties of Foeniculum vulgare (dulce or sweet, vulgare or bitter, and azoricum or Florence) exhibited a marked antifungal activity against Aspergillus niger (Marotti et al. 1994).

Lippia alba essential oil was the most effective of essential oils extracted from various parts of 11 higher plants for their fungitoxicity against a range of fungal sugarcane pathogens. L. alba essential oil was fungistatic against Colletotrichum falcatum (Glomerella Tucumanensis) and C. pallescens at $700 \mathrm{ppm}$ or less, and fungicidal at higher concentrations against all the other test pathogens such as: Fusarium moniliforme, Ceratocystis paradoxa, Rhizoctonia solani, Curvularia lunata, Periconia atropurpuria and Epicoccum nigrum (Singh et al. 1998).

A positive correlation between the monoterpene content of the oils (other than limonene and sesquiterpenes) and fungal inhibition was observed in an experiment testing the effect of volatile components of citrus fruit essential oils on Penicillium digitatum and P. italicum. P. digitatum was found to be more sensitive to the inhibitory action of the oils than P. italicum (Caccioni et al. 1998).

Essential oils extracted from leaves of $\mathrm{Oci}$ mum canum (O. americanum) and seeds of Anethum graveolens and Pimpenella anisum completely inhibited the growth of fungi at 3000 ppm. P. anisum oil showed fungicidal activity at 3000 ppm against $C$. falcatum, $C$. paradoxa and $P$. solani (Singh et al. 1998). (+)-limonene, cineole, $\beta$-myrcene, $\alpha$-pinene, $\beta$-pinene and camphor showed high antifungal activity against Botrytis cinerea (Wilson et al. 1997). Volatiles from crushed tomato leaves inhibited hyphal growth of Alternaria alternata isolated from lesions of tobacco leaves and Botrytis cinerea isolated from infected strawberry fruit. Aldehydes, including $\mathrm{C}_{6}$ and $\mathrm{C}_{9}$ compounds, formed by lipoxygenase enzyme pathway upon wounding leaves, inhibited growth of both species. Terpene hydrocarbons, 2-carene, and limonene had no significant effect on hyphal growth (HamiltonKemp et al. 1992). Cardamom oil inhibited the growth of A. flavus, A. parasiticus A. ochraceus, Penicillium sp., $P$. patulum, $P$. roquefortii and $P$. citrinum, and of its components $\alpha$-terpinyl acetate had the greatest antifungal spectrum, followed by linalool, limonene, and cineole (Badei 1992). In agar diffusion experiments the essential oil of Tagetes minuta inhibited the multiplication of fungi and showed $100 \%$ of inhibition (Hethelyi et al. 1986, 1987). 
Ibrahim, M.A. et al. Limonene in pest control

\section{Nematodes}

(+)-limonene at $100 \mathrm{ppm}$ reduced the Heterodera schachtii population to less than $3 \%$ of the control after 3 months, when sugarbeet seedlings cv. SSY1 were inoculated with 2300 freshly hatched $H$. schachtii J2. However, root growth was also reduced by phytotoxic effects of (+)limonene (Viglierchio and Wu 1989). Aqueous extracts of $H$. suaveolens leaves gave $100 \%$ mortality of Meloidogyne incognita larvae in 80 mins, whereas the whole oil gave $100 \%$ mortality in 30 mins. The nematicidal activity is therefore linked to the essential oil of $H$. suaveolens, of which (+)-limonene and menthol are two main constituents (Babu and Sukul 1990).

\section{Mites}

(-)-limonene, $\beta$-pinene, $\alpha$-pinene and $\Delta_{3}$-carene were toxic to adult females of the spruce spider mite Oligonychus ununguis when exposed for 24 hrs at concentrations below the calculated LC50s. All four compounds decreased oviposition in the mites while three of these compounds (limonene, $\beta$-pinene, and $\alpha$-pinene) influenced movement (Cook 1992). Monoterpene vapours from peppermint have similar toxic effects on the spider mite Tetranychus urticae (Larson and Berry 1984). Acute toxicity of 34 naturally occurring monoterpenes were evaluated against T. urticae and most of the monoterpenes were lethal to the mite at high concentrations; carvomenthenol and terpinen-4-ol were especially effective (Lee et al. 1997).

\section{Insects}

Secondary plant metabolites play an important role in plant resistance to insects. Monoterpenes including limonene can be bioassayed to determine their possible fumigant, contact, and ingestion activity against insect pests and other pathogens. These substances can be toxic via penetration of the insect cuticle (contact effect), via the respiratory system (fumigant effect) and via the digestive apparatus (ingestion effect) (Prates et al. 1998).

Insecticidal use of limonene has been successfully applied for the control of insect parasitoids of pet animals. Weekly application of (+)limonene reduced flea and tick infestations by $80 \%$ in $24 \operatorname{dogs}$ and one cat, with no adverse effects on blood composition or liver and kidney function (Tonelli 1987). (+)-limonene was toxic to all life stages of the cat flea, Ctenocephalides felis (Hink and Fee 1986). (+)limonene has shown to have efficacy against malathion-resistant fleas (Collart and Hink 1986), but dogs developed toxicity effects including extensive erythema, and therefore it should be used cautiously (Rosenbaum and Kerlin 1995). Limonene has shown insecticidal properties against human blood-sucking insects when tested against early $4^{\text {th }}$ instar larvae of the mosquito Culex quinquefasciatus. The LC50 was $53.80 \mathrm{ppm}$ after $24 \mathrm{~h}$ and $32.52 \mathrm{ppm}$ after $48 \mathrm{~h}$. Limonene-treated water was less favourable than untreated water for oviposition by females of the mosquito (Kassir et al. 1989). The oil of Myrica gale acts as a deterrent to biting midge Culicoides impunctatus, but limonene together with camphene and terpinene-4-ol were at the bottom of the scale of the activity (Stuart and Stuart 1998).

Some monoterpene showed efficacy against food and wood pests. Components (cymol and limonene) of the essential oils of Eucalyptus camaldulensis, E. cameroni, and of the peal of Citrus aurantium have significant insecticidal action, being lethal to the stored product pests Rhyzopertha dominica and Tribolium castaneum. (+)-limonene showed more effective control of $T$. castaneum than of $R$. dominica (Santos et al. 1997). A study carried out by Sharma and Raina (1998) indicated that linalool, citronellal, and carvone showed promising toxicity against the termite Odontotermes brunneus, while, eucalyptol, terpinene, and limonene did not show much activity. Application of high doses of (+)limonene or linalool to oothecal (egg save) of gravid female of German cockroach (Blatella 
Vol. 10 (2001): 243-259.

germanica) decreased significantly the probability of young emerging from them, but did not affect female mortality (Karr and Coats 1992). Untreated diet was significantly preferred compared with diet treated with high levels of (+)limonene, linalool, and $\alpha$-terpineol. However, (+)-limonene among other tested compounds reduced significantly the time required by cockroaches' nymphs to reach the adult stage (Karr and Coats 1992).

Limonene has been shown to be toxic to several bark beetles e.g. the Southern pine beetle, Dendroctonus frontalis (Coyne and Lott 1976), the Western pine beetle D. brevicomis (Smith 1975 ) and the mountain pine beetle $D$. ponderosae (Raffa and Berryman 1983). Laboratory bioassay indicated that myrcene, limonene and $\beta$ phellandrene applied topically at $20 \mathrm{ppm}$ were toxic to $60 \%$ of adult spruce beetles, D. rufipennis (Werner and Illmann 1994). The vapours of the monoterpenes present in grand fir (Abies grandis) phloem caused a significant mortality of the fir engraver beetle (Scolytus ventralis). Toxicity was observed at doses normally found in the host tree, either in the attacked phloem or in the reaction tissue induced by the associated fungi (Raffa et al. 1985).

The substances dihydrocarvone and carvone were repelled the blow fly, Protophormia terraenovae in a net cage study. Other compounds like eucalyptol, limonene, p-cymene, gammaterpinene, dihydrocarvyl-acetate, $\beta$-pinene, $\beta$ myrcene, eugenol, and $\alpha$-humulene seemed to have a deterrent effect mainly by contact of the fly with the treated bait at concentrations of 17$25 \mu \mathrm{molcm}^{-2}$ (Thorsell et al. 1989). The essential oils of $0.5 \mathrm{~g}$ citrus including (+)-limonene, $\alpha$-pinene, and myrcene caused rapid knockdown (KT50) on Musca domestica in 10-20s, and also inhibition of the emergence rate of the pupae increased with the increased exposure time. The same dose of oils killed all treated flies within 24h (Liao and Liao 1999).

The internal concentration of limonene in plants or in artificial food of herbivorous insects has significant effects on the behaviour and food consumption of plant feeding insects (Table 2).
Most of the studies indicate the attractive role of limonene for herbivorous insects of conifers, which have a high content of monoterpenes in their oleoresin. For specialised herbivores limonene can be a signal compound to detect the right host plant species of certain plant family as shown with Trioza apicalis by Valterova et al. (1997). The same carrot pest (T. apicalis) can even avoid carrot varieties with high limonene content (Kainulainen et al. 2001).

\section{Phytotoxicity}

Plant injuries from chemicals are called phytotoxicity, and are manifested in several ways. Leaf tips, margins, or the entire leaf surface can appear burned, growing tips and buds can be killed and roots can also be burned. Chlorosis or yellowing of leaves (in spots, along margins) or a general chlorosis of the entire leaf or leaf distortion may appear as curling, crinkling, or cupping of the leaf. Stunting of growth on all or parts of the plant is also one of the phytotoxic impacts. Phytotoxic chemicals can also stimulate abnormal either excessive growth (as aerial roots and suckering), or elimination and distortion of fruit or flowers. Symptoms of phytotoxicity can be confused with insect or mite damage, diseases, and other abiotic problems such as nutrient deficiencies, or environmental conditions (Fink 1999).

Phytotoxicity of some naturally occurring monoterpenes were tested on maize plant, and some of them have shown phytotoxicity to maize roots and leaves. On the other hand, D-Carvone was the most phytotoxic, whereas pulegone was the safest (Lee et al. 1997). But on the other hand, carvone inhibited sprouting of treated potato tubers during storage with low persistence. Carvone has to be reapplied about every 3 months during storage. The low persistence means that tubers could be consumed as soon as 15 days after treatment. Carvone also inhibited early sprouting of seed tubers (Reust 2000). In the Netherlands, carvone has been introduced as a commercial sprouting inhibitor for potatoes 


\section{Ibrahim, M.A. et al. Limonene in pest control}

Table 2. Summary of reports indicating negative or positive effects of internal limonene concentrations in plants or in artificial food on plant damaging insects.

\begin{tabular}{|c|c|c|c|}
\hline Insect species & Host plant & Response & Reference \\
\hline & & Reduced activity of pest insect & \\
\hline $\begin{array}{l}\text { Pissodes strobi } \\
\text { (Coleoptera: } \\
\text { Curcullionidae) } \\
\text { - Pine shoot feeder }\end{array}$ & $\begin{array}{l}\text { Paired agar disc } \\
\text { bioassay }\end{array}$ & $\begin{array}{l}\text { Limonene inhibited feeding at high } \\
\text { concentration. }\end{array}$ & Alfaro et al. 1980 \\
\hline $\begin{array}{l}\text { Diaphania nitidalis } \\
\text { (Lepidoptera, Pyralidae) } \\
\text { - Pickleworm moth }\end{array}$ & $\begin{array}{l}\text { Treated on artificial } \\
\text { sites }\end{array}$ & $\begin{array}{l}\text { A concentration of } 20 \mu 1 \text { of }(-)- \\
\text { limonene } 96 \% \text { caused slight but } \\
\text { significant reduction in oviposition. }\end{array}$ & Peterson et al. 1994 \\
\hline $\begin{array}{l}\text { Trioza apicalis } \\
\text { (Homoptera: Psyllidae) } \\
\text { - carrot sucker }\end{array}$ & $\begin{array}{l}\text { Various Apiacea } \\
\text { species }\end{array}$ & $\begin{array}{l}\text { Large amounts of either }(-) \text { or }(+)- \\
\text { limonene were released by the } \\
\text { Apiacea species of low preference of } \\
\text { T. apicalis. }\end{array}$ & Valterova et al. 1997 \\
\hline $\begin{array}{l}\text { Dioryctria zimmermanni, } \\
\text { (Lepidoptera: Pyralidae) } \\
\text { - pine trunk borer }\end{array}$ & $\begin{array}{l}\text { Scots pine, Pinus } \\
\text { sylvestris }\end{array}$ & $\begin{array}{l}\text { Resistant proveniences emitted } \\
\text { relatively high levels of limonene. } \\
\text { Increased activity of pest insect }\end{array}$ & Sadof \& Grant 1997 \\
\hline $\begin{array}{l}\text { Pissodes strobi } \\
\text { (Coleoptera: } \\
\text { Curcullionidae) } \\
\text { - Pine shoot feeder }\end{array}$ & $\begin{array}{l}\text { Paired agar disc } \\
\text { bioassay }\end{array}$ & $\begin{array}{l}\text { Limonene stimulated feeding at low } \\
\text { concentration. }\end{array}$ & Alfaro et al. 1980 \\
\hline $\begin{array}{l}\text { Pissodes strobi } \\
\text { - pine shoot feeder }\end{array}$ & $\begin{array}{l}\text { Eastern white pine, } \\
\text { Pinus strobus }\end{array}$ & $\begin{array}{l}\text { Limonene concentration was highest } \\
\text { in trees attacked most frequently. }\end{array}$ & Wilkinson 1980 \\
\hline $\begin{array}{l}\text { Dioryctria abietivorella } \\
\text { (Lepidoptera: Pyralidae) } \\
\text { - twig borer }\end{array}$ & $\begin{array}{l}\text { Eastern white pine, } \\
\text { Pinus strobus }\end{array}$ & $\begin{array}{l}\text { Ten microliters of a test solution } \\
\text { containing } 10 \mu \mathrm{g}(-) \text {-limonene } 95 \% \\
\text { elicited a significant oviposition } \\
\text { response, but was the least stimulating } \\
\text { monoterpene in EAG tests. }\end{array}$ & Shu et al. 1997 \\
\hline $\begin{array}{l}\text { Cydia strobilella } \\
\text { (Lepidoptera: Tortricidae) } \\
\text { - spruce seed moth }\end{array}$ & $\begin{array}{l}\text { Norway spruce, } \\
\text { Picea abies }\end{array}$ & $\begin{array}{l}\text { Limonene elicited the highest } \\
\text { electroantennogram response, } \\
\text { probably cue compound for ovipositing } \\
\text { females. }\end{array}$ & Åhman et al. 1988 \\
\hline $\begin{array}{l}\text { Dioryctria amatella } \\
\text { (Lepidoptera: Pyralidae) } \\
\text { - Southern pine coneworm }\end{array}$ & $\begin{array}{l}\text { Loblolly pine, } \\
\text { Pinus taeda }\end{array}$ & $\begin{array}{l}\text { Combination of }(+) \text {-limonene, } \\
\alpha \text {-pinene, and myrcene was attractive } \\
\text { to females. }\end{array}$ & Hanula et al .1985 \\
\hline $\begin{array}{l}\text { Dioryctria sylvestrella } \\
\text { (Lepidoptera: Pyralidae) } \\
\text { - maritime stem borer }\end{array}$ & $\begin{array}{l}\text { Maritime pine, } \\
\text { Pinus pinaster }\end{array}$ & $\begin{array}{l}\text { Attacked trees contained a significantly } \\
\text { higher percentage of limonene together } \\
\text { with longipinene and copaene. }\end{array}$ & Jactel et al. 1996 \\
\hline $\begin{array}{l}\text { Thecodiplosis japonensis } \\
\text { (Diptera: Cecidomyiidae) } \\
\text { - Pine gall midge }\end{array}$ & $\begin{array}{l}\text { Japanese pine, } \\
\text { Pinus thunbergii }\end{array}$ & $\begin{array}{l}\text { Higher limonene and } \beta \text {-pinene contents } \\
\text { were associated to resistance. }\end{array}$ & Kim et al. 1976 \\
\hline
\end{tabular}

(Bouwmeester et al. 1995). Limonene oxide and linalool both inhibited sprouting and fungal growth but tubers were soft after exposure.
Limonene and $\alpha$-pinene did not inhibit sprouting, and fungal growth was present on every tuber treated (Vaughn and Spencer 1991). Because 
Vol. 10 (2001): 243-259.

of the phytotoxicity, monoterpenes may be a potential source of products used for haulm killing and weed control.

(+)-limonene is highly phytotoxic to sugarbeet seedlings (CV. SSY 1) at high concentrations (Viglierchio and Wu 1989). Carvone, (+)limonene, and (-)-limonene were either less effective and/or more phytotoxic to wheat, barley and perennial ryegrass when seed dressing to control slugs were tested (Nijenstein and Ester 1998). Preliminary tests showed that limonene has phytotoxic activity at concentrations more than 3\% to strawberry (cv. Jonsok and Honeoye) seedlings (Ibrahim 2000). Our preliminary observations suggest that cabbage and carrot seedlings are sensitive to limonene at the concentration of 9\% (Ibrahim et al., unpublished results). In general, there is not much information available on the phytotoxicity threshold values of monoterpenes to different cultivated plants.

\section{Suitability of limonene in control of plant-damaging insect pests}

\section{Insecticidal use}

Experiments dealing with the use of monoterpenes extracted from plants like insecticides in plant protection are scarce. For insect pests that associated with plant roots, drenching with toxic monoterpene solution might increase larval mortality and reduce damage, but may also affect other soil animals (Karr et al. 1990). A wide range of monoterpenes has larvicidal effects on the western corn rootworm in the soil and effectively protects corn roots from attack by this larva under greenhouse conditions (Lee et al. 1997).

\section{Deterrent}

Internal limonene concentrations in plants have shown deterrent effects on only few insect pests
(Table 2). Among these the carrot psyllid (T. apicalis) has shown a reduced oviposition rate on carrot varieties having a high concentration of limonene (Kainulainen et al. 2001). This observation suggests that, the selection of carrot varieties with high limonene contents can be used to reduce carrot psyllid damages in the areas, where the risk of damage is high. The selection of resistant varieties may be a suitable method for pest control in organic farming, but the factors determining pest deterrence should be known.

Exogenous treatment of cultivated plants with limonene extracted from other plant species have more often reduced insect attack than increased and attracted pest insects (Table 3 ). In leaf disk tests to estimate deterrent effects of (+)limonene on larvae of Galerucella sagittariae (Coleoptera: Chrysomelidae) (Holopainen et al. 2000), plants from two strawberry varieties (Honeoye and Jonsok) were treated with $1 \%(+)$ limonene, $1 \%$ mixture $(75: 25 \%)$ of $(+)$-limonene and (+)-carvone, and water in fumehood. The leaf discs (diam. $15 \mathrm{~mm}$ ) were cut with a cylinder tube from strawberry leaves. For choice tests three leaf discs (one from each treatment) were put into Petri dish on filter paper, 2 hours and 24 hours after the treatment, one larva of G. sagittariae was immediately released into the middle of the Petri dish. After monitoring 24 hours the eaten area from the leaf discs by the larva was estimated visually.

Spraying of leaves with limonene or mixture of limonene and carvone did not significantly reduced the feeding ability of the larvae of G. sagittariae on leaf discs of the variety Honeoye if offered to the larvae 2 or 24 hours after spraying of leaves (Fig. 1a). In the test with strawberry variety Jonsok, larvae did not prefer feeding on leaf disk offered $2 \mathrm{~h}$ after spraying, but limonene and, limonene and carvone in mixture significantly reduced feeding when leaf disks were offered to larvae $24 \mathrm{hrs}$ after spraying (Fig. 1b). The result suggests that carvone in mixture with limonene can be as effective as pure limonene to reduce G. sagittariae larval feeding on certain strawberry varieties. For the 


\section{Ibrahim, M.A. et al. Limonene in pest control}

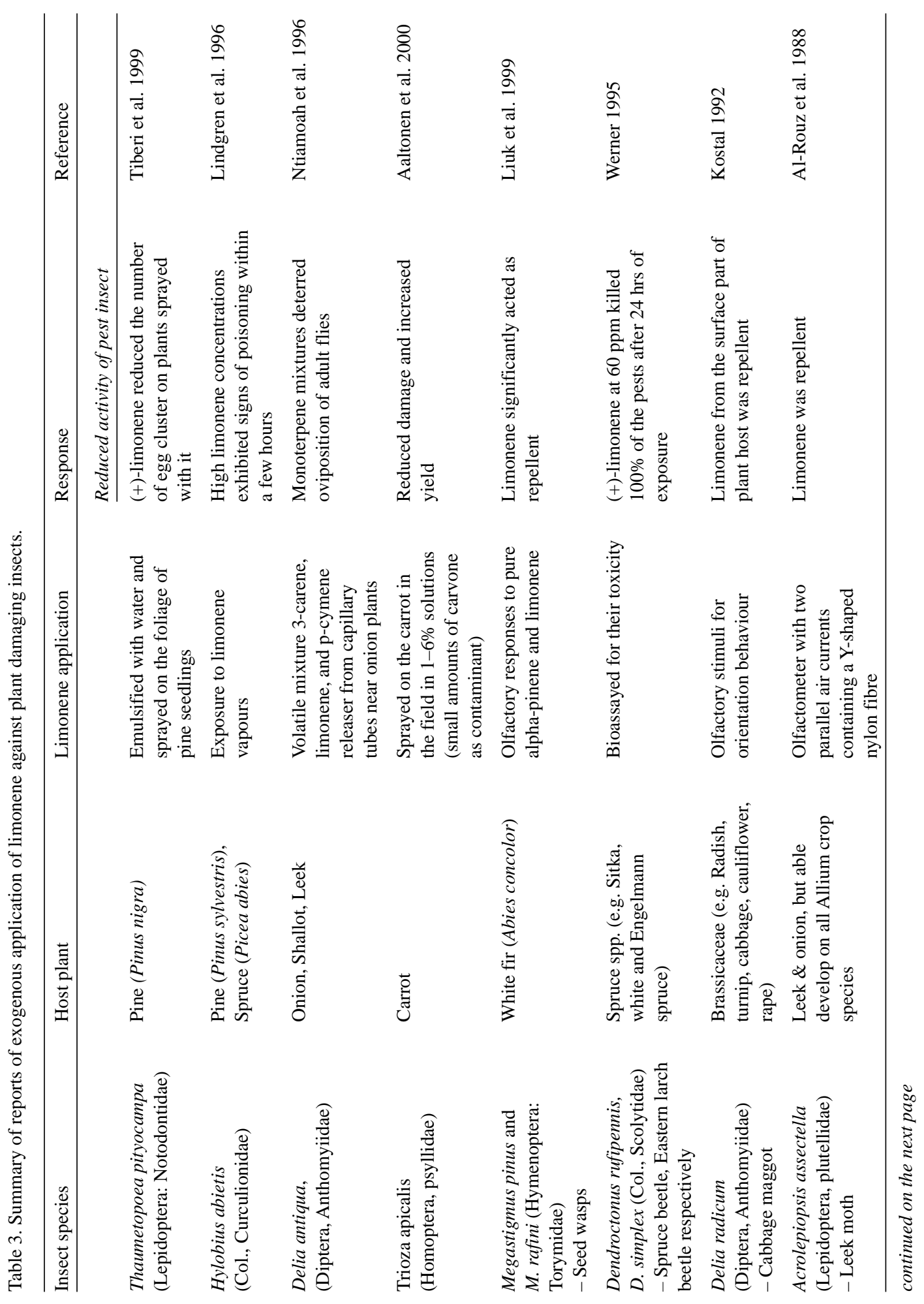


Vol. 10 (2001): 243-259.

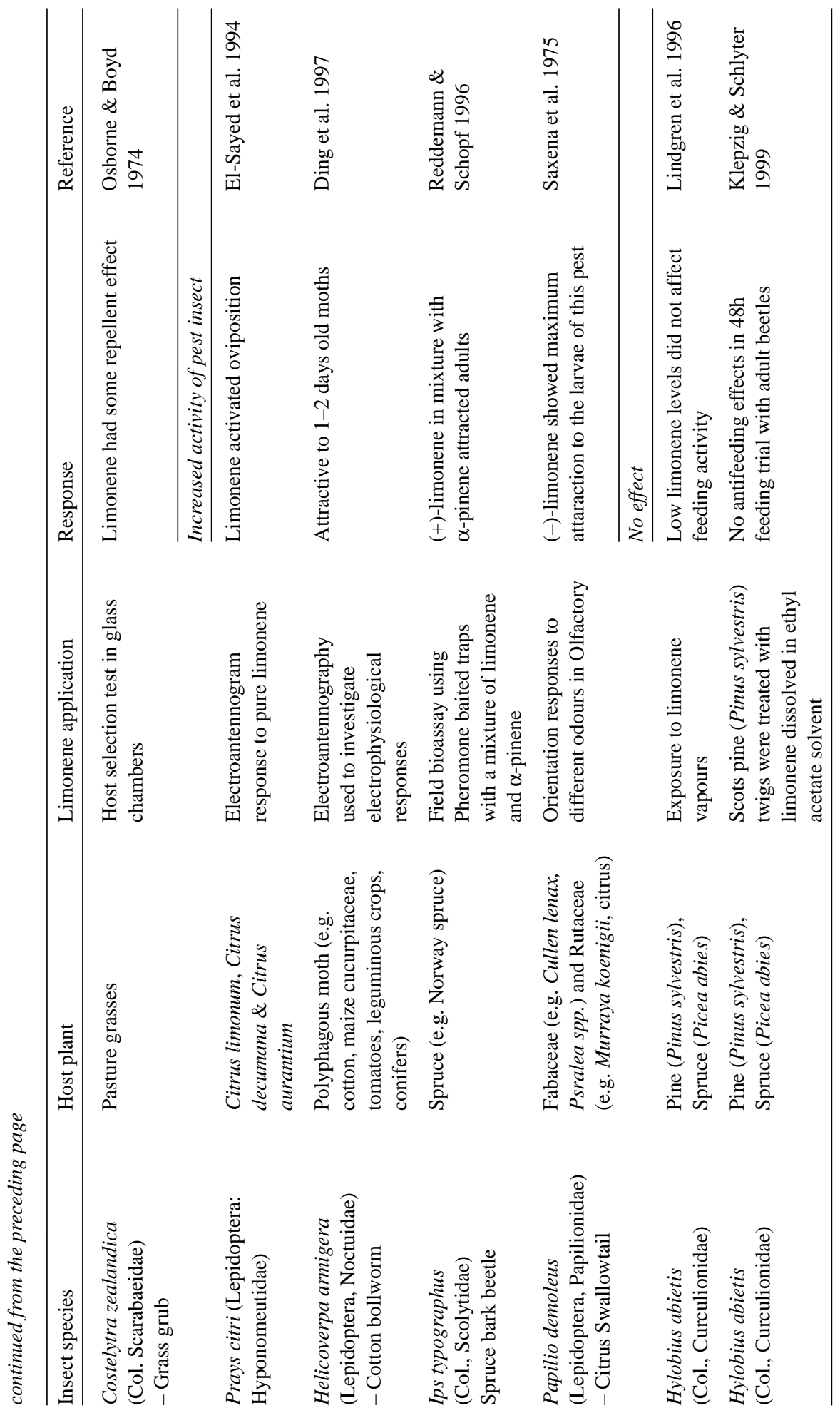


Ibrahim, M.A. et al. Limonene in pest control

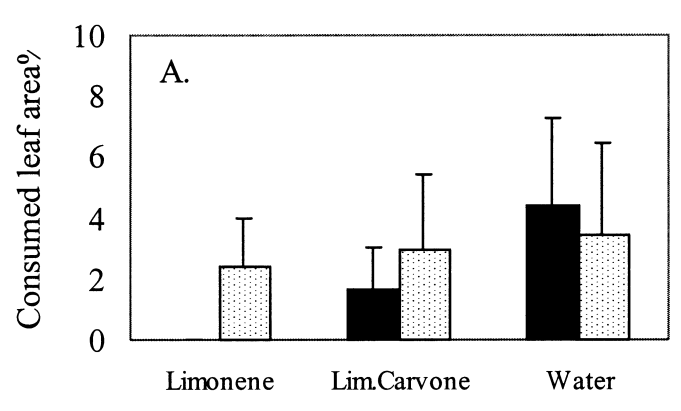

Treatment

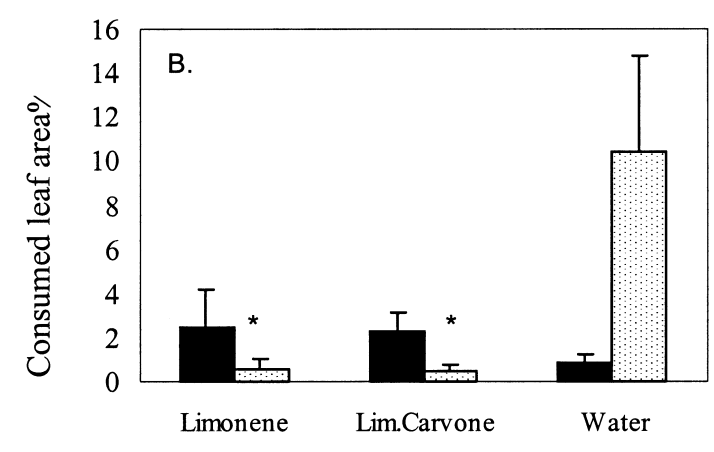

Treatment

Fig. 1. The effect of $1 \%$ limonene treatment on the feeding of the larvae Galerucella sagittariae on cv. Honeoye (A) and cv. Jonsok (B) leaf discs when larvae were put into the Petri dishes for feeding $2 \mathrm{~h}$ (black bars) and $24 \mathrm{~h}$ after spraying (grey bars). Asterisk above bar indicate significant $(\mathrm{P}<$ 0.05 ) difference from the control (water) treatment according to oneway anova.

confirmation of results, field tests are needed, since high concentration of volatile compounds inside closed Petri dishes may reduce larval feeding also on control treatment as observed with the variety Jonsok when offered leaf discs sprayed only $2 \mathrm{~h}$ before feeding trial (Fig. 1b).

Field sprays of Pinus uncinata with oleoresin extracts of $P$. cembra cones significantly reduced the overall damage of specialized cone insects. None of the cones sprayed with oleoresin were attacked, whereas insects damaged $11 \%$ and $31 \%$ of the unsprayed control cones (Dormont et al. 1997). Several compounds including the major component of all citrus peel oils, (+)limonene, were found to be bioactive, having a strong vapour insecticidal activity, against the cowpea weevil beetle Callosobruchus maculatus (Coleoptera: Bruchidae) (Don-Pedro 1996).

Limonene, mixed with the combination of $\alpha$ pinene and ethanol on old clear cuttings, inhibited completely the catch of Hylobius pinastri (Coleoptera: Curculionidae) and that of $\mathrm{H}$. abietis was reduced by two thirds. On fresh clear cuttings the inhibitory effect of limonene was small or absent (Nordlander 1990). Volatile oils of baladi orange and mandarin peels, which contain over $70 \%$ limonene, were highly toxic to $2^{\text {nd }}$ larval instar stage of Spodoptera littoralis. Their toxicity consistently increased with increasing concentration of the volatile oils. The results from this experiment suggest that these volatile oils could be used as larval growth disruptors and also as repellent materials against moths for controlling programme of cotton leaf worm S. littoralis (Omer et al. 1997). Sesquiterpenes, in combination with tricyclene, camphene, myrcene, limonene, terpinolene, and the acetate fraction appear to be an effective mixture of defensive compounds against the western spruce budworm (Zou and Cates 1997).

Ntiamoah and Borden (1996) found that, a ternary mixture of carene, limonene and pcymene in the choice bioassay significantly deterred the oviposition of cabbage maggots, but the deterrence was slight in the non-choice bioassay. Increasing the complexity of the blend to six monoterpenes increased the deterrent effect markedly. These results indicate that, as for onion maggots (Ntiamoah et al. 1996), monoterpenes are oviposition deterrents for cabbage maggots. The results also suggest that monoterpenes may be oviposition deterrents for other anthomyiids. Combining various deterrents used in different areas may develop a way of pest control more valuable than by using single deterrent. 


\section{Effects on non-target organisms and manipulation of natural enemies}

Although the acute toxicity of monoterpenoids is low relative to that of conventional insecticides (Lee et al. 1997), the effects of field scale use on soil and water animals should be tested further. Potential drifts to aquatic ecosystem may have effects on food chains, since mortality of aquatic dipterans have increased after limonene treatment (Kassir et al. 1989). Toxic effects on earthworms (Karr et al. 1990) should be clarified more extensively, since potential pesticide use of limonene in organic farming may be harmful for whole agroecosystem if earthworm populations are reduced.

Also selectivity and harmlessness of limonene toward natural enemies and other biological agents needs testing. Interaction with entomopathogenes such as Bacillus thuringiensis should be understood. The potential use of limonene and other monoterpenes in integrated pest management can be achieved with the knowledge of all these interactions. For rapid attraction of large numbers of nestmates to newly discovered food sources, the polyphagous predator ant Myrmicaria eumenoides uses an efficient recruitment communication system based on the poison gland secretion that includes mainly $(+)$ limonene (Kaib and Dittebrand 1990). This observation suggests that a better understanding of the communication systems of predators and parasitoids may offer novel ways to increase the efficiency of natural enemies of pest insects with limonene and other monoterpenes.

\section{Summary and future perspectives}

Monoterpenes distilled from plants have effects on many bacterial, fungal, nematode and arthropod species and some compounds are effective sprouting inhibitors. The monoterpene limonene has shown deterrent and insecticide properties suggesting that as a plant-based natural product it might have use in pest control in organic agriculture. Possible attractive effects of limonene to natural enemies of pests may offer novel applications to use natural compounds for manipulation of beneficial animals in organic agriculture. However, since monoterpenes are phytotoxic to several cultivated plants, critical thresholds of limonene for plant physiology and limonene sensitivity should be determined. Also the potential harmful effects on natural enemies of pests and non-target soil animals should be investigated. After these evaluations, suitable recommendations for the use of limonene on specific crop plant species and against specific pest species can be given.

Acknowledgements. We thank Dr. G.V.P. Reddy for discussions and the comments on the manuscript and Dr. Simo Lötjönen for the information of limonene nomenclature. The work was funded by the Ministry of Agriculture and Forestry in Finland (MTT-project no: 130581) and Jenny and Antti Wihuri Foundation.

\section{References}

Aaltonen, M., Aflatuni, A. \& Parikka, P. 2000. Limoneenilla kemppi kuriin. Puutarha \& Kauppa 4, 16: 4-5.

Åhman, I., Wiersma, N. \& Lindström, M. 1988. Electroantennogram responses in Cydia strobilella (L.) (Lepidoptera: Tortricidae) to flower and twig odours of its host Picea abies (L.) Karst. Journal of Applied Entomology 105: 314-316.

Alfaro, R.I., Pierce, H.D. Jr., Borden, J.H. \& Oehlschlag- er, A.C. 1980. Role of volatile and nonvolatile components of Sitka spruce bark as feeding stimulants for Pissodes strobi Peck (Coleoptera: Curcullionidae). Canadian Journal of Zoology 58: 626-632.

Al-Rouz, H., Thibout, E. \& Rouz, H.A.L. 1988. Olfactory responses to plant allelochemicals in Acrolepiopsis assectella larvae. Entomologia Experimentalis et Applicata 47: 231-237. 
Ibrahim, M.A. et al. Limonene in pest control

Babu, S.P. \& Sukul, N.C. 1990. Essential oils as nematicidal principles. Environment and Ecology 8: 11181120.

Badei, A.Z.M. 1992. Antimycotic effect of cardamum essential oil components on toxigenic molds. Journal of Egyptian Food Science 20: 441-452.

Benner, J.P. 1993. Pesticidal compounds from higher plants. Pesticide Science 39: 95-102.

Biondi, D., Cianci, P., Geraci, C., Ruperto, G. \& Piattelli, M. 1993. Antimicrobial activity and chemical composition of essential oils from Sicilian aromatic plants. Flavour and Fragrance Journal 8: 331-337.

Bouwmeester, J.H., Davies, J.A. \& Toxopeus, H. 1995. Enantiomeric composition of carvone, limonene, and carveols in seeds of dill and annual and biennial caraway varieties. Journal of Agricultural and Food Chemistry 43: 3057-3064.

Brattesten, L.B. 1983. Cytochrome P-450 involvement in the interactions between plant terpenes and insect herbivores. In: Hedin, P.A. (ed.). Plant resistance to insects. American Chemical Society, Washington, DC. p. $173-195$.

Caccioni, D.R., Guizzardi, M., Biondi, D.M., Renda, A. \& Ruberto, G. 1998. Relationship between volatile components of citrus fruit essential oils and antimicrobial action of Benicillium ditatum and Penicillium italicum. International Journal of Food Microbiology 43: 73-79.

Chanegriha, N., Sabaou, N., Baaliiouamer, A. \& Meklati, B.Y. 1994. Antibacterial and antifungal activity of the essential oil of Algerian cypress. Rivista Italiana EP. POS 12: 5-12.

Collart, M.G. \& Hink, W.F. 1986. Development of resistance to malathion in cat flea (Siphonaptera: Pulicidae). Journal of Economic Entomology 79: 15701572.

Cook, S.P. 1992. Influence of monoterpene vapors on spruce spider mite Oligonychus ununguis adult females. Journal of Chemical Ecology 18: 1497-1504.

Coyne, J.F. \& Lott, L.H. 1976. Toxicity of substances in pine oleoresin to southern pine beetles. Journal of the Georgia Entomological Society 11: 301-305.

Cox, S.D., Mann, C.M., Markham, J.L., Bell, H.C., Gustafson, J.E., Warmington, J.R. \& Wyllie, S.G. 2000. The mode of antimicrobial action of the essential oil of Melaleuca alternifolia (tea tree oil). Journal of Applied Microbiology 88: 170-175.

Croteau, R. 1987. Biosynthesis and catabolism of monoterpenoids. Chemical Reviews 87: 929-954.

Crowell, P.L. 1999. Prevention and therapy of cancer by dietary monoterpenes. Journal of Nutrition 129: 775778.

Dell, B. \& McComb, A.J. 1981. Plant resins - Their formation, secretion and possible functions. Advances in Botanical Research 6: 278-316.

Ding, H.J., Guo, Y.Y. \& Wu, C.H. 1997. Isolation and identification of semiochemicals from carrot flower and behavioural responses in cotton bollworm moths. Acta Entomologica Sinica 40: 73-78.

Don-Pedro, K.N. 1996. Investigation of single and joint fumigant insecticidal action of citrus peel oil components. Pesticide Science 46: 79-84.
Dormont, L., Roques, A. \& Malosse, C. 1997. Efficiency of spraying mountain pine cones with oleoresin of Swiss stone pine cones to prevent insect attack. Journal of Chemical Ecology 23: 2261-2274.

Duke, S.O., Keeler, R.F. \& Tu, A.T. (eds.). 1991. Plant terpenoids as pesticides. In: Handbook of natural toxins. Vol.6. Toxicology of plant and fungal compounds. Marcel Dekker, Inc., New York, USA. p. 269-296.

El-Sayed, E.M., Talaat, M.S., Desouki, S. \& Sheashaa, M.A. 1994. Bioelectrical activity of citrus flower moth, Prays citri and host plant selection for oviposition. Egyptian Journal of Biomedical Engineering 10: 3148.

Fessenden, R.J., Fessenden, J.S. \& Logue, M. 1998. Organic Chemistry. $6^{\text {th }}$ ed. Pacific Grove. Brooks/Cole. $1168 \mathrm{p}$.

Fink, S. 1999. Pathological and regenerative plant anatomy. Berlin. Gebrüder Borntraeger. 1095 p.

Flamini, G., Cioni, P.L., Puleo, R., Morelli, I. \& Panizzi, L. 1999. Antimicrobial activity of the essential oil of Calamintha nepeta and its constituent pulegone against bacteria and fungi. Phytotherapy Research 13: 349-351.

Fournier, G., Hadjiakhoondi, A., Leboeuf, M., Cave, A., Fuorniat, J. \& Charles, B. 1993. Chemical and biological studies of Xylopia longifolia A. DC. Essential oils. Journal of Essential Oil Research 5: 403-410.

Gershenzon, J. \& Croteau, R. 1991. Terpenoids. In: Rosenthal, G.A. \& Berenbaum, M.R. (eds.). Herbivores. Their Interactions with secondary plant metabolites. Academic Press, San Diego. p. 165-219.

Hamilton-Kemp, T.R., McCkracken, C.T. Jr., Loughrin, J.H., Andersen, R.A. \& Hildebrand, D.F. 1992. Effects of some natural volatile compounds on the pathogenic fungi Alternaria alternata and Botrytis cinerea. Journal of Chemical Ecology 18: 1083-1091.

Hanula, J.L., Berisford, C.W. \& DeBarr, G.L. 1985. Monoterpene oviposition stimulants of Dioryctria amatella in volatiles from fusiform rust galls and second-year loblolly pine cones. Journal of Chemical Ecology 11 : 943-952.

Harborne, J.B. 1993. Introduction to ecological biochemistry. Fourth edition, Academic Press, Cambridge. $318 \mathrm{p}$.

Helander, I.M., Alakomi, H.-L., Kyösti, L.-K., Mattila-Sandholm, T., Pol, I., Smid, E.J., Gorris, L.G.M. \& Wright, A.V. 1998. Characterization of the action of selected essential oil components on Gram-Negative bacteria. Journal of Agricultural and Food Chemistry 46: 3590-3595.

Hethelyi, E., Danos, B., Tetenyi, P. \& Koczka, I. 1987. GC/ MS analysis of the essential oils of four tagetes species and the microbial activity of Tagetes minuta. Herba Hungarica 26: 49-61.

-, Tetenyi, P., Kozka, I. \& Domokos, J. 1986. Essential oil components and antimicrobial activity of Cotinus coggygria. Herba Hungarica 25: 73-85.

Hink, W.F. \& Fee, B.J. 1986. Toxicity of D-limonene, the major component of citrus peel oil, to all life stages of the cat flea, Ctenocephalides felis (Siphonaptera: Pulicidae). Journal of Medical Entomology 23: 400404. 
Vol. 10 (2001): 243-259.

Holopainen, J., Ibrahim, M.A., Aflatuni, A. \& Tiilikkala, K. 2000. Limoneenin mahdollisuudet mansikan tuholaistorjunnassa. Puutarha \& Kauppa 47/2000 plus: 1617.

Hooser, S.B. 1990. Toxicology of selected pesticides, drugs, and chemicals. D-limonene, linalool, and crude citrus oil extracts. Toxicology of selected pesticides, Drugs, and Chemicals 20: 383-385.

Hough-Goldstein, J.A. 1990. Antifeedant effects of common herbs on the Colorado potato beetle (Coleoptera: Chrysomelidae). Environmental Entomology 19: 234-238.

Ibrahim, M.A. 2000. Feeding of leaf beetle (Galerucella sagittariae) on Strawberry leaflets sprayed with plant volatiles. M.Sc. Thesis. University of Kuopio, Department of Ecology and Environmental Science, $46 \mathrm{p}$.

Iwu, M.M., Ezeugwu, C.O., Okunji, C.O., Sanson, D.R. \& Tempesta, M.S. 1990. Antimicrobial activity and terpenoids of the essential oil of Hyptis suaveolens. International Journal of Crude Drug Research 28: 7376.

Jactel, H., Kleinhentz, M., Marpeau-Bezard, A., Marion, P. \& Burban, C. 1996. Terpene variations in maritime pine constitutive oleoresin related to host tree selection by Dioryctria sylvestrella Ratz. (Lepidoptera: Pyralidae). Journal of Chemical Ecology 22: 10371050.

Janssen, A.M., Scheffer, J.J., Svendsen, A.B., Aynehchi, Y. \& Baerheim-Svendsen, A. 1984. The essential oil of Ducrosia Anethifolia (DC.) Boiss. Pharmaceuutisch weekblad, Scientific edition 6: 157-160.

Kaib, M. \& Dittebrand, H. 1990. The poison gland of the ant Myrmicaria eumenoides and its role in recruitment communication. Chemoecology 1: 3-11.

Kainulainen, P., Nissinen, A., Piirainen, A., Tiilikkala, K. \& Holopainen, J.K. 2001.Essential oil composition in leaves of carrot varieties and preference of specialist and generalist sucking insect herbivores. (submitted manuscript).

Karr, L.L. \& Coats, J.R. 1992. Effects of monoterpenoids on growth and reproduction of the German cockroach (Blattodae: Blattellidae). Journal of Economic Entomology 85: 425-429.

-, Drewes, C.D. \& Coats, J.R. 1990. Toxic effects of dlimonene in the earthworm Eisenia fetida (Savigny). Pesticide Biochemistry and Physiology 36: 175-186.

Kassir, J.T., Mohsen, Z.H., \& Mehdi, N.S. 1989. Toxic effects of limonene against Culex quinquefasciatus Say larvae and its interference with oviposition. Anzeiger für Schädlingskunde, Pflanzenschutz, Umweltschutz 62: 19-21.

Kim, C.S., Hong, S.H., Ryu, J.B, Choi, C., Kim, J.S. \& Kim, D.S. 1976. Breeding of varieties of pines resistant to pine gall midge. II. Seasonal variation of needle monoterpene composition in resistant Pinus thunbergii. Korean Journal of Breeding 8: 137-142.

Klepzig, K.D. \& Schlyter, F. 1999. Laboratory evaluation of plant-derived antifeedants against the pine weevil Hylobius abietis (Coleoptera: Curculionidae). Journal of Economic Entomology 92: 644-650.

Kostal, V. 1992. Orientation behaviour of newly hatched larvae of the cabbage maggot, Delia radicum (L.)
(Diptera: Anthymiidae), to volatile plant metabolites. Journal of Insect Behavior 5: 61-70.

Langenheim, J.H. 1994. Higher plant terpenoids: A phytocentric overview of their ecological roles. Journal of Chemical Ecology 20: 1223-1280.

Larson, K.C. \& Berry, R.E. 1984. Influence of Peppermint phenolics and monoterpenes on twospotted spidermite (Acari: Tetranychidae). Environmental Entomology 13: 282-285.

Laska, M. \& Teubner, P. 1999. Olfactory discrimination ability of human subjects for ten pairs of enantiomers. Chemical Senses 24: 161-170.

Lee, S., Tsao, R., Peterson, C., Coates, J.R. \& Lee, S.K. 1997. Insecticidal activity of monoterpenoids to western corn rootworm (Coleoptera: Chrysomelidae), twospotted spidermite (Acari: Tetranychidae), and housefly (Diptera: Muscidae). Journal of Economic Entomology 90: 883-892.

Liao, S. \& Liao, S.C. 1999. Mortality and repellency effects of essential oils from citrus against the housefly and German cockroach. Chinese Journal of Entomology 19: 153-160.

Lichtenthaler, H.K., Schwender, J., Disch, A. \& Rohmer, M. 1997. Biosynthesis of isoprenoids in higher plant chloroplasts proceeds via a mevalonate-independent pathway. FEBS Letters 400: 271-274.

Lindgren, B.S., Nordlander, G. \& Birgersson, G. 1996. Feeding deterrence of verbenone to the pine weevil, Hylobius abietis (L.) (Coleoptera: Curculionidae). Journal of Applied Entomology 120: 397-403.

Little, D.B. \& Croteau, R.B. 1999. Biochemistry of essential oil terpenes. A thirty year overview. In: Teranishi, L. \& Wick, E.L. (eds). Flavor Chemistry: 30 years of progress. Kluwer Academic/Plenum Publishers, New York. p. 239-253.

Liuk, A., Ochsner, P. \& Jensen, T. 1999. Olfactory responses of seed wasps Megastigmus pinus parfitt and Megastigmus rafni Hoffmeyer (Hymenoptera: Torymidae) to host tree odours and some monoterpenes. Journal of Applied Entomology 123: 561-567.

Marotti, M., Piccaglia, R., Giovanelli, E., Deans, S.G. \& Eaglesham, E. 1994. Effects of variety and ontogenic stage on the essential oil composition and biological activity of fennel (Foeniculum vulgare Mill.). Journal of Essential Oil Research 6: 57-62.

Naigre, R., Kalck, P., Roques, C., Roux, I. \& Michel, G. 1996. Comparison of antimicrobial properties of monoterpenes and their carbonylated products. Planta medica 62: 275-277.

Needham, J. 1986. Science and Civilization in China. vol. 6, 1. Cambridge University Press, Cambridge.

Nijenstein, J.H. \& Ester, A. 1998. Phytotoxicity and control of the field slug Deroceras reticulatum by seed applied pesticides in wheat, barley and perennial ryegrass. Seed Science and Technology 26: 501-513.

Nordlander, G. 1990. Limonene inhibits attraction to apinene in the pine weevils Hylobius abietis and $H$. pinastri. Journal of Chemical Ecology 16: 1307-1320.

Ntiamoah, Y.A., Borden, J.H. \& Pierce, H.D. Jr. 1996. Identity and bioactivity of oviposition deterrents in pine oil for the onion maggot (Delia antiqua). Entomologia Experimentalis et Applicata 79: 219-226. 
Ibrahim, M.A. et al. Limonene in pest control

- \& Borden, J.H. 1996. Monoterpene oviposition deterrents for cabbage maggots, Delia Radicum (L.) (Diptera: Anthomyiidae). Canadian Entomologist 128: 351-352.

Omer, E.A., Youssef, A.A., Abo-Zeid, E.N. \& Sharaby, A.M. 1997. Biochemical studies on the essential oils of Balady orange and mandarin. Egyptian Journal of Horticulture 24: 207-218.

Osborne, G.O. \& Boyd, J.F. 1974. Chemical attractants for larvae of Cotelytra zealandica (Coleoptera: Scarabaeidae). New Zealand Journal of Zoology 1: 371374.

Peterson, J.K., Horvat, R.J. \& Elsey, K.D. 1994. Squash leaf glandular trichome volatiles: Identification and influence on behaviour of female pickleworm moth [Diaphania nitidalis (Stoll.)] (Lepidoptera: Pyralidae). Journal of Chemical Ecology 20: 2099-2109.

Phillips, M.A. \& Croteau, R.B. 1999. Resin-based defenses in conifers. Trends in Plant Science 4: 184-190.

Prates, H.T., Santos, J.P., Waquil, J.M., Fabris, J.D., OIiveira, A.B. \& Foster, J.E. 1998. Insecticidal activity of monoterpenes against Ryzopertha dominica (F.) and Tribolium castaneum (Herbst). Journal of Stored Products Research 34: 243-249.

Raffa, K.F. \& Berryman, A.A. 1983. Physiological aspects of lodgepole pine wound responses to a fungal sympiont of mountain pine beetle Dendroctonus ponderosae (Coleoptera: Scolytidae). Canadian Entomologist 115: 723-734.

-, Berryman, A.A., Simasko, J., Teal, W. \& Wong, B.L. 1985. Effects of grand fir monoterpenes on the fir engraver, Scolytus ventralis (Coleoptera: Scolytidae), and its symbiotic fungus. Environmental Entomology 14: 552-556.

Reddemann, J. \& Schopf, R. 1996. The importance of monoterpenes in the aggregation of the spruce bark beetle Ips typographus (Coleoptera: Scolytidae). Entomologia Generalis 21: 69-80.

Reust, W. 2000. Carvone, a new natural sprouting inhibitor for potato storage. Revue Suisse d'Agriculture 32: 150-152.

Rosenbaum, M.R. \& Kerlin, R.L. 1995. Erythema multiforme major and disseminated intravascular coagulation in a dog following application of a d-limonene based insecticidal dip. Journal of the American Veterinary Medical Association 207: 1315-1319.

Sadof, C.S. \& Grant, G.G. 1997. Monoterpene composition of Pinus sylvestris varieties resistant and susceptible to Dioryctria zimmermani. Journal of Chemical Ecology 23: 1917-1927.

Santos, J.P., Prates, H.T., Waquil, J.M. \& Oliveiria, A.B. 1997. Evaluation of plant origin substances on the control of stored product pests . Pesquisa emm Andamento Centro Nacional de Pesquisa de Milho e sorgo no. $19.18 \mathrm{p}$.

Saxena, K.N., Prabha, S. \& Shashi-Brabha 1975. Relationship between the olfactory sensilla of Papilio demolius L. Larvae and their orientation responses to different odours. Journal of Applied Entomology 50: 119-126.

Schütte, H.R. 1984. Secondary plant substances. Monoterpenes. Progress in Botany 46: 119-139.
Sharma, R.N. \& Saxena, K.N. 1974. Orientation and developmental inhibition in the housefly by certain terpenoids. Journal of Medical Entomology 11:617-621.

- \& Raina, R.M. 1998. Evaluating chemicals for ecofriendly pest management. I: Terpenoids and fatty acids for building termites. Journal of Scientific and Industrial Research 57: 306-309.

Shu, S., Grant, G.G., Langevin, D., Lombardo, D.A. \& MacDonald, L. 1997. Oviposition and electroantennogram responses of Dioryctria abietivorella (Lepidoptera: Pyralidae) elicited by monoterpenes and enantiomers from eastern white pine. Journal of Chemical Ecology 23: 35-50.

Singh, S.P., Rao, G.P. \& Upadyaya, P.P. 1998. Fungitoxicity of essential oil of some aromatic plants against sugar cane pathogens. Sugarcane 2: 14-17.

Smith, A.E. \& Secoy, D.M. 1981. Plants used for agricultural pest control in Western Europe before 1850. Chemical Industry 3: 12-17.

Smith, R.H. 1975. Formula for describing effect of insect and host tree factors on resistance to western pine beetle attack. Journal of Economical Entomology 68: 841-844.

Soliman, F.M., El-Kashoury, E.A., Dathy, M.M. \& Gonaid, M.H. 1994. Analysis and biological activity of the essential oil of Rosmarinus officinalis L. Egyptian Journal of Flavour and Fragrance 9: 29-33.

Stuart, A.E. \& Stuart, C.L.E. 1998. A microscope slide test for the evaluation of insect repellents as used with Culicoides impunctatus. Entomologia Experimentalis et Applicata 89: 277-280.

Takaisi-Kikuni, N.B., Tshilanda, D. \& Babady, B. 2000. Antibacterial activity of the essential oil of Cymbopogon Densiflorus. Fitoterapia 71: 69-71.

Thorsell, W., Mikiver, A., Malm, E. \& Mikiver, M. 1989. Fly repellents from extracts of Mentha spicata X crispata. Studies on Protophormia terraenovae. Entomologisk Tidskrift 110: 109-112.

Tiberi, R., Niccoli, A., Curini, M., Epifano, F., Marcotullio, M.C. \& Rosati, O. 1999. The role of the monoterpene composition in Pinus spp. Needles, in host selection by the pine processionary caterpillar, Thaumetopea pityocampa. Phytoparasitica 27: 263-272.

Tonelli, E.A. 1987. Experimental use of d-limonene in dips for the treatment of flea and tick infestations in small animals. Veterinaria Argentina 4: 931-937.

Valterova, I., Nehlin, G. \& Borg-Karlson, A.K. 1997. Host plant chemistry and preferences in egg-laying Trioza apicalis (Homoptera: Psylloidea). Biochemical Systematics and Ecology 25: 477-491.

Vaughn, S. \& Spencer, G.F. 1991. Volatile monoterpenes inhibit potato tuber sprouting. American Potato Journal 68: 821-831.

Viglierchio, D.R. \& Wu, F.F. 1989. Selected biological inhibitors for Heterodera schachtii control. Nematropica 19: 75-79.

Vila, R., Valenzuela, L., Bello, H., Canigueral, S., Montes, M. \& Adzet, T. 1999. Composition and antimicrobial activity of the essential oil of Peumus boldus leaves. Planta medica 65: 178-179.

Watanabe, K., Shono, Y., Kakimizu, A., Okada, A., Matsuo, N., Satoh, A. \& Nishimura, H. 1993. New mos- 
Vol. 10 (2001): 243-259.

quito repellent from Eucalyptus camaldulensis. Journal of Agricultural and Food Chemistry 41: 21642166.

Weidenhamer, J.D., Macias, F.A., Fischer, N.H. \& Williamson, G.B. 1993. Just how insoluble are monoterpenes? Journal of Chemical Ecology 19: 1799-1807.

Werner, R.A. 1995. Toxicity and repellency of 4-allylanisole and monoterpenes from white spruce and tamarrac to the spruce beetle and eastern larch beetle (Coleoptera: Scolytidae). Environmental Entomology 24: 372-379.

- \& Illmann, B.L. 1994. The role of stilbene-like compounds in host tree resistance of Sitka spruce to the spruce beetle, Dendroctonus rufipennis. In: Proceedings, behavior, population dynamics and control of forest insect conference. 6-11 February 1994, Mani, Hi. OARDC/ Ohio State University, Wooster, OH.
Wilkinson, R.C. 1980. Relationship between cortical monoterpenes and susceptibility of eastern white pine to white-pine weevil attack. Forest Science 26: 581589.

Wilson, C.L., Solar, G.M., El-Ghaouth, A. \& Wisniewski, M.E. 1997. Rapid evaluation of plant extracts and essential oils for antifungal activity against Botrytis cinerea. Plant Disease 81: 204-210.

Yang, R.Z. \& Tang, C.S. 1988. Plants used for Pests'control in China, a literature review. Economic Botany 42: 376-406.

Zou, J. \& Cates, R.G. 1997. Effects of terpenes and phenolic and flavonoid glycosodes from Douglas fir on Western spruce budworm larval growth, pupal weight, and adult weight. Journal of Chemical Ecology 23: 2313-2326.

\title{
SELOSTUS
}

\section{Monoterpeenit kasvinsuojelussa: erityisesti limoneenin vaikutus eri eliöryhmiin}

\author{
Mohamed A. Ibrahim, Pirjo Kainulainen, Abbas Aflatuni, Kari Tiilikkala ja Jarmo K. Holopainen \\ Kuopion yliopisto ja MTT (Maa- ja elintarviketalouden tutkimuskeskus)
}

Kiinnostus luonnonmukaisiin, kasveista peräisin oleviin ja vähemmän terveys- ja ympäristöhaittoja aiheuttaviin torjunta-aineisiin on lisääntynyt luomuviljelyn yleistyessä. Tässä katsauksessa selvitetään monoterpeenien käyttömahdollisuuksia kasvinsuojelussa ja arvioidaan erityisesti limoneenin vaikutuksia eri eliöryhmiin. Limoneenilla on torjuttu lemmikkieläinten ulkoloisia, mutta sen on todettu tehoavan myös moniin muihin hyönteisiin, punkkeihin ja mikrobeihin. Sekä karkottavaa että myrkkyvaikutusta on havaittu. Limoneenin houkuttavuus tuhohyönteisten luontaisille vihollisille voi tarjota mahdollisuuden käyttää sitä luomuviljelyyn sopivana biologisena tor- juntamenetelmänä, jossa tuholaisten luontaisia vihollisia houkutellaan kasvustoon ennen tuholaisia. Joissain tapauksissa limoneenilla käsitellyt kasvit voivat kuitenkin altistua tuholaisille limoneenikäsittelyn seurauksena, ja korkeilla pitoisuuksilla limoneeni on kasveille myrkyllinen. Kasviperäisinä luonnontuotteina limoneenista ja muista monoterpeeneistä voi tulla luomuviljelyyn sopivia tuhoeläinten ja rikkakasvien torjunta-aineita. Tämä kuitenkin edellyttää, että aineiden mahdolliset haittavaikutukset viljelykasveihin, maaperäeliöstöön ja tuholaisten luontaisiin vihollisiin ensin selvitetään. 